EuIter

Douglas K. McCormick

RESEARCH BOTOR

Harvey Bialy

SEAIOR EDTOAs

Jennifer Van Brunt

Arthur Klausner

\section{CONmIBUmino EDTOAS}

Peter Newmark

Jeffrey L. Fox

EDTORLAL ASSISTANT

Caroline Schneider

ART DIRECTOR

Dennis Ahlgrim

PRODUCTON MaNAGg

Donna Zuckerman

\section{PUBLISHER}

Gary M. Rekstad

\section{ADVERTISING SALS MMAGER}

George F. Cominsky

EUROPEAM ADVERTSING

\section{SAIES MAMACE}

Hilary Turnbull

CRCULAMON BIRECTOR

James Skowrenski

FULFLUMET MAUACER

W. Paige Beaver

FIITORIAL CORRESPONDENCE:

BU/THCHNOHOGY, 65 Bleecker St. New York, NY 10012. Telephone: (212) 477-9600). Telex: 668497UW BIO/TECHNOLOGY, 4 Little Essex Street, London WC:2R 31.F. Telephone: (01) 8366633 . Telex: 262024.

\section{SCIEITIFIC ADUISORY BOARI}

\section{CHAIRMAN}

George Poste, Smith Kline \& French

Pharmaceutical Development

Ronald E. Cape

Cetus Corporation

Mary-Dell Chilton, CIBA-Geigy

Plant Molecular Biology

Carlo Croce, Wistar Institute

Monoclonal Antibodies

Arnold Demain, MIT

Secondary Metabolism and Fermentation

Stanley Falkow, Stanford

Medicine and Vaccine Development

David Goeddel, Genentech

Recombinant DNA Products

Benjamin Hall, Univ. of Washington

Yeast Genetics

Ernest Jaworski, Monsanto

Plant Biotechnology

Ephraim Katchalski-Katzir

Tel Aviv University

Immobilized Enzymes and Polymers

Allen Laskin, N.J. Center for Advanced

Biotechnology and Medicine

Hydrocarbons and Polysaccharides

Malcolm Lilly, University College

London, Biochemical Engineering

David Mount, University of Arizona

Computer Applications

Carl-Gustaf Rosen, Alfa-Laval

Biochemical Engineering

Yukio Sugino, Takeda

Cancer Chemotherapy

Lemuel B. Wingard, University of

Pittsburgh, Enzyme Engineering and Biosensors

To supplement coverage of Japanese developments, BIO/TECHNOLOGY has an editoria liaison with the editorial staff of Japan Chemical Daily, Ltd. and Japan Chemical Week.

\section{THE FIRST WORD}

\section{GENENTECH BOUND}

What are we angry about this month?" we groused from the editorial lair. That's the way editorials usually start: A stint as a theater critic brought home the lesson that bile makes better copy than benevolence, that vitriol flows more happily from the pen than honey.

Well, Jeremy Rifkin continues to be annoying-like the stinging gadfly that drives the poor stolid cattle mad. What has he got against cows, anyway? First a vendetta sworn against milk producers who dare to experiment with bovine somatotropin. And now a demand that the government look into a connection between beef and AIDS (or, more particularly, a bovine retrovirus and AIDS). Is it a plot to foist vegetarianism on the U.S.?

Ah, but empty vessels resound only when they are beaten; the weather is hot, and our arms and ears are tired of that particular pastime.

Instead, we have been thinking about poor Genentech (an uncommon conjunction of noun and modifier). First there was the spectacle of Genentech and sometime cohort Eli Lilly battling in court over human growth hormone-fighting for custody of an orphan who happens to have a handsome inheritance. Next, a Food and Drug Administration advisory board recommended against approving the company's tissue-type plasminogen activator for emergency treatment of acute myocardial infarction (a decision curiously at odds with the evidence that seems to be available, as we discussed last month). Then a Wall Street Journal story blamed that decision not on the advisory board's capriciousness but on the company's inexperience, and even sloppiness, in assembling its application. And after that, Genentech lost a challenge to its British patent on t-PA.

Hubris was the central fact of Greek tragedy-the regrettable tendency of the great to think that they have somehow overcome the forces of nature, history, and fate. They were invariably punished for it-and the greater the arrogation of divine power, the greater the punishment. The greatest punishment of all, of course, was reserved for Prometheus, who lightfingered virtually all of the divine arts and parcelled them out to a pitiful mortal species marked for destruction-man.

A passage from Prometheus Bound is painted on the rotunda ceiling at the National Academy of Sciences. It is part of a speech by Prometheus-pinned by bronze spikes to the rocks of the Caucasus at the command of Zeus-to Io, a young woman desired by Zeus, turned into a cow by Zeus's jealous wife, and pursued across three continents by a demonic unsleeping gadfly.

"Hear what troubles there were among men," says Prometheus, "how I found them witless and gave them the use of their wits and made them masters of their minds...."

Prometheus goes on to list his gifts to mankind-fire, the habit of hope in place of a certain knowledge of the future, mathematics, writing, domesticated animals, and the wheel. But, he concludes,

Greatest was this: in the former times if a man fell sick he had no defense against the sickness, neither healing food nor drink nor unguent; but through the lack of drugs men wasted away, until I showed them the blending of mild simples wherewith they drive out all manner of diseases.

In other words, you do your best to bring people the best available medical technology and you get pilloried for it.

The agony eventually ended (though it took 2,300 years for Shelley to write the sequel-Hollywood would have followed it up much quicker), but the gifts, wherever they really came from, remain. Perhaps today's discomfitted biotech companies should remember that. Abraham Lincoln liked quote the old Hebrew story about a satrap who asked his wise men for a motto or lesson that would be always true and always worth remembering. The sages' reply: "And this, too, shall pass away."

"How much it expresses!" said Lincoln. "How chastening in the hour of pride! How consoling in the depths of affliction!" -Douglas McCormick 